\title{
A Comparative Study on Group-Based LearningUsing STAD and SGD Toward Students' Writing Achievement of Descriptive Text
}

\author{
Sri Wahyuni \\ UIN Walisongo Semarang \\ wahyunii041@gmail.com
}

\begin{abstract}
This study discusses a comparative study of group-based learning method between STAD and SGD toward students' writing achievement of descriptive text on the tenth grade of SMK SalafiyahKajen in the academic year of 2017/2018. The purpose of the study was to differentiate those two methods, which were then found the appropriate method between STAD and SGD for learning writing skill. This study used a mixed method by using comparative design. The subject of this study were the students at the tenth grade of SMK SalafiyahKajen, students' class RPL 2 and TB. The students from both of the class had different treatment which RPL 2 was treated using SGD and TB was treated using STAD. The technique of data collection was a test, observation, and documentation. The test consisted of two tests; they were pre-test and post-test. After collecting the data, it was found that the average score of pre-test of SGD group was 50.06 and for STAD group was 47.75; meanwhile, the average score of post-test of SGD group was 68.70 and for STAD group was 63.10. So, the computation of $t$ count was 5.031, and the $t$ table was 1.69. The $t$ count was higher than $t$ table, which stated that Ha was accepted. It meant that there was a significant difference between students' writing achievement which was taught by using STAD and SGD. The conclusion defined that SGD was better than STAD to be applied in learning writing.
\end{abstract}

\author{
ARTICLE HISTORY \\ Received 6 July 2018 \\ Accepted 16 August 2018

\section{KEYWORDS} \\ Small group discussion; \\ students-team \\ achievement division; \\ students' writing \\ achievement; writing \\ achievement
}

\section{Introduction}

Teaching and learning English in the way of maximizing each effort in improving student's proficiency level takes place in its process since all of the skills need different treatment.Writing is one the skill in learning English. Learning to write is a difficult and complex series of processes that require a range of explicit teaching methodologies throughout all the stages of learning. The importance of the methodologies then used by teachers in their teaching activities as the act to support the students' success in learning writing.Every learning method has its strengths and weaknesses, but in the learning process teachers who have a role as a facilitator should help the students to learn and have the skills which are needed to achieve the 
learning objectives. In order to get the goal of learning it requires teachers to be able to apply some various kind of learning method which represents the students' need.

Cooperative Learning is one of active learning. It refers to various kind of learning method that students work in a small group to help each other in studying. It is interesting when students are actively engaged with other students to share their idea. They do not only learn but also are equipped with the skills of teamwork directly in the learning process. The example of Cooperative Learning that writer take for learning writing in order to maximize students' writing descriptive text is Student-Team Achievement Division (STAD). Student-Team Achievement Division is a learning activity which supports students to get used to work in a group and help each other in solving a problem that is followed by students' responsibility. This type of Cooperative Learning is easy to be adapted. It has been used for some subjects such as Science, History, English and any other subjects from elementary up to college as well.

Teaching writing using STAD in this case hopefully be able to increase students' learning achievement. It also leads students to be able to work in a group that may become such an alternative to make all students be able to learn collaboratively to reach the maximal result for their writing achievement.

Student-Team Achievement Division STAD as group-based learning cannot be considered valid since the writer has not proven yet in research. It also cannot be said appropriate to be applied when another group-based learning method claim that the method they have been researched show the increase in students' writing. One of the examples is the research which has been conducted by students of Tanjungpura University Pontianak, Edy Rahmat. By the title Improving Student's Achievement in Procedure Text Writing through Small Group Discussion Technique (A QuasiExperimental Study to the tenth-grade students of SMAN 1 SukadanaKayong Utara Regency, in the academic year 2011/2012). Edy Rahmat stated that after being taught using SGD (Small Group Discussion) method students' writing skill was improved by sharing their knowledge, ideas and experiences when they find the best words (word choice) for writing descriptive text, organizing text structure and using language features appropriately.

To know which one is better to be applied between STAD and SGD, the writer then refers to conduct research by the case of those two learning methods by comparing them. Based on the background above researcher then formulates the following research questions: how the students' writing achievement of descriptive text taught using STAD is, how the students' writing achievement of descriptive text is taught using SGD, and what the differences are between students' writing achievement of descriptive text taught using STAD and SGD. The research itself was conducted at the tenth-grade students of SMK SalafiyahKajen in the academic year 2017/2018. 
Related to the research questions above, the objectives of the research are to examine the STAD method on students' writing achievement of descriptive texts, to examine the SGD method on students' writing achievement of descriptive text and to know the differences between students' writing achievement of descriptive text using STAD and SGD method.

The result of this research also expected to be useful information to The first benefit is to motivate students. It allowsteachers to teach in a more satisfying way rather than just giving instructions through the textbook. Hopefully, this research gives more information and contribute knowledge to the reader and become an additional reference for the next improvement research.

\section{The Review of Related Literature}

The researcher found some studies that had been conducted and related to this study: 1. Edy Rahmat, in the research he conducted the study by some problems happened, that in learning writing of procedure text students faced some difficulties such as word choice, organizing the generic structure and the use of the imperative verb.By applying Small Group Discussion, the researcher found some improvement that seen from the result of the test. The improvement had been helped by the use of pictures as a teaching aid in supporting the technique in order to ease the students in gaining and developing their imagination. 2. NurikaMustika, the study was to find out how Student Teams-Achievement Divisions (STAD) could improve students' descriptive writing ability. This study conducted by the students' problems that they faced in learning writing such as first, the students have difficulty in arranging sentence; second, they have a problem in sharing their ideas into written text; third, they lack to practice because most of the activity was focused and emphasized on speaking.Using Class Action Research whichthe research result that showed from the from thetwo cycles percentage of students score, it could be concluded that STAD (Student Achievement Divisions) was able to improve students' descriptive writing ability by having heterogeneous teams in terms of ability and gender that made them easy in generating their ideas and able to have peer tutoring. Besides, teams reward also help a student in motivating them to achieve the target of writing. It can be seen by the percentage of students' participation that always increased in each cycle.

Writing sometimes becomes a challenging course for some learners since this kind of skill is produced. Different from the receiving skill that students do not need to produce language. Language production is seen as an active process of meaning construction and expression. It means that in learning writing students require special attention or action than only receiving knowledge from the teacher. As a productive skill, writing is seen not just as a standardized system of communication but also as an essential tool for learning. It does not mean that writing cannot instantly comprehend. Learning to write involves much more than merely learning 
the grammar and vocabulary of the language, or even the rhetorical form common to academic writing.

The ability to write effectively is becoming increasingly important in our global community, and instruction in writing is thus assuming an increasing role in both second- and foreign-language. The essence of writing itself then become such a tool to interact with each other, to other community, communication across language throughout the world. So that why writing as a widely recognized as an essential skill has function whether for educational, business and personal reasons as well.

In the form of communication, writing is organized from the simple arrangement of the word, but it needs more additional arrangements from word to clause then phrase, sentence, paragraph, and text. Those sequence arrangements used, in order to make a useful and meaningful writing language which be able to be understood by the readers. While in writing there are also several processes that should be done in order to get better writing. According to Thomas S Kane, the steps included in the writing process are thinking, drafting and revising. The first step, "thinking," involves choosing a subject, exploring ways of developing it, and devising strategies of organization and style. The second step, "doing," is usually called "drafting"; and the third, "doing again," is "revising."

So then, why does the researcher choose STAD and SGD in teaching writing? Such had been stated in the background of the research both of the method is to represent the group-based learning method that only can be applied in learning English especially writing. They both have the same rule as the learning method that leads students to work together in order to avoid inequality of students' achievement in learning.

STAD is Robert Slavin, and his friends developed a model at Johns Hopkin University, a variation model which the most studied of cooperative learning. The model has been applied in some courses such as science, social and English. It can also be applied from the level elementary until college.In STAD, students are divided into groups of four students with different abilities, gender, and tribe. The teacher delivers a lesson, and the students within the group ensure that all members of the group can master the lesson.The steps of Learning of STAD include a) Delivering goals and motivation. b) Division of groups. c) Presentation from the teacher. d) Teaching-learning activities (teamwork). e) Quiz (evaluation). f) Team achievement award

While SGD small group interaction is a process by which three or more group members exchange verbal and non-verbal messages in an attempt to influence one another. The sequence of activities which is done in SGD there are a) Presentation. b) Process. c) Ending. d) Feedback.

In this research, the researcher applied the Students-Team Achievement Division in class TB and applied the Small Group Discussion in class RPL 2. The meeting both of the class were done in three meetings. 


\section{Method}

In this research, the researcher used a mixed method approach by using comparative design.In this study researcher conduct research because of comparing two methods of group-based learning there are STAD and SGD. The comparison itself comes from the researcher curiosity that in some researches those two methods implied that they are just as gave powerful influences in learning writing. So that, to know which is the appropriate one to be applied in learning writing the researcher then intend to conduct this comparative research. It is implemented on learning writing, especially on writing descriptive text. To find out the most appropriate method in learning writing both STAD and SGD, researcher firstly examines those two methods in each class. There are two classes which each of them researcher use STAD and SGD in students' learning writing. Some data collection technique found the result of the study. While to examine the validity of the data, it was used some statistical techniques according to comparative design.

The steps for conducting comparative research itself were mentioned as follow:

1. Identify a research problem.

2. Select a defined group and a comparison group.

3. Collect data on relevant independent and dependent variables and relevant background characteristics.

4.Analyze and interpret the data, with a particular focus on competing explanations.

First, a research problem was identified. Here the researcher examines the differences in group-based learning method in learning writing by using STAD and SGD. The implications for many students were regarding improving the cooperative skill and took advantage of learning in the group in order to increase their achievement in learning writing.

The second step in conducting comparative research was selecting a defined group and a comparison group. The defined group in this research was the STAD learning method while the comparison group was SGD learning method. Both of the two methods were treated differently according to each step of learning. This was done as well as to explain the differentiation between the groups.

The third step in a comparative study involved collecting data on the independent and dependent variables as well as on relevant background characteristics. The independent variables included the use of STAD and SGD method to teach writing a specifically descriptive text while the dependent variable is students' achievement learning writing of the descriptive text.

The fourth step involved analyzing and interpreting the data. For the researcher, analysis of the data includes several steps: First, the researchers gained the data from the students' test result. Moreover, then, calculated correlations to 
examine the relationship between STAD learning method and SGD learning method data.

\section{Data Analysis}

The score of first ability (pre-test), based on the calculations of normality, homogeneity test, both of classes were a normal distribution and homogenous. The scoring average of SGD group was 50,06 and STAD group was 47,75. While for the score of last ability (post-test), based on the result of this research was obtained the average score of the SGD group was 68.70 which were higher than the STAD group was 63.10. The computation of $t$ count was 5.031, and the $t$ table was 1.69 , the $t$ count was higher than $t$ table, which stated that Ha was accepted. It answered the hypothesis that there were significant differences between STAD and SGD.

Table 1.Results of data analysis

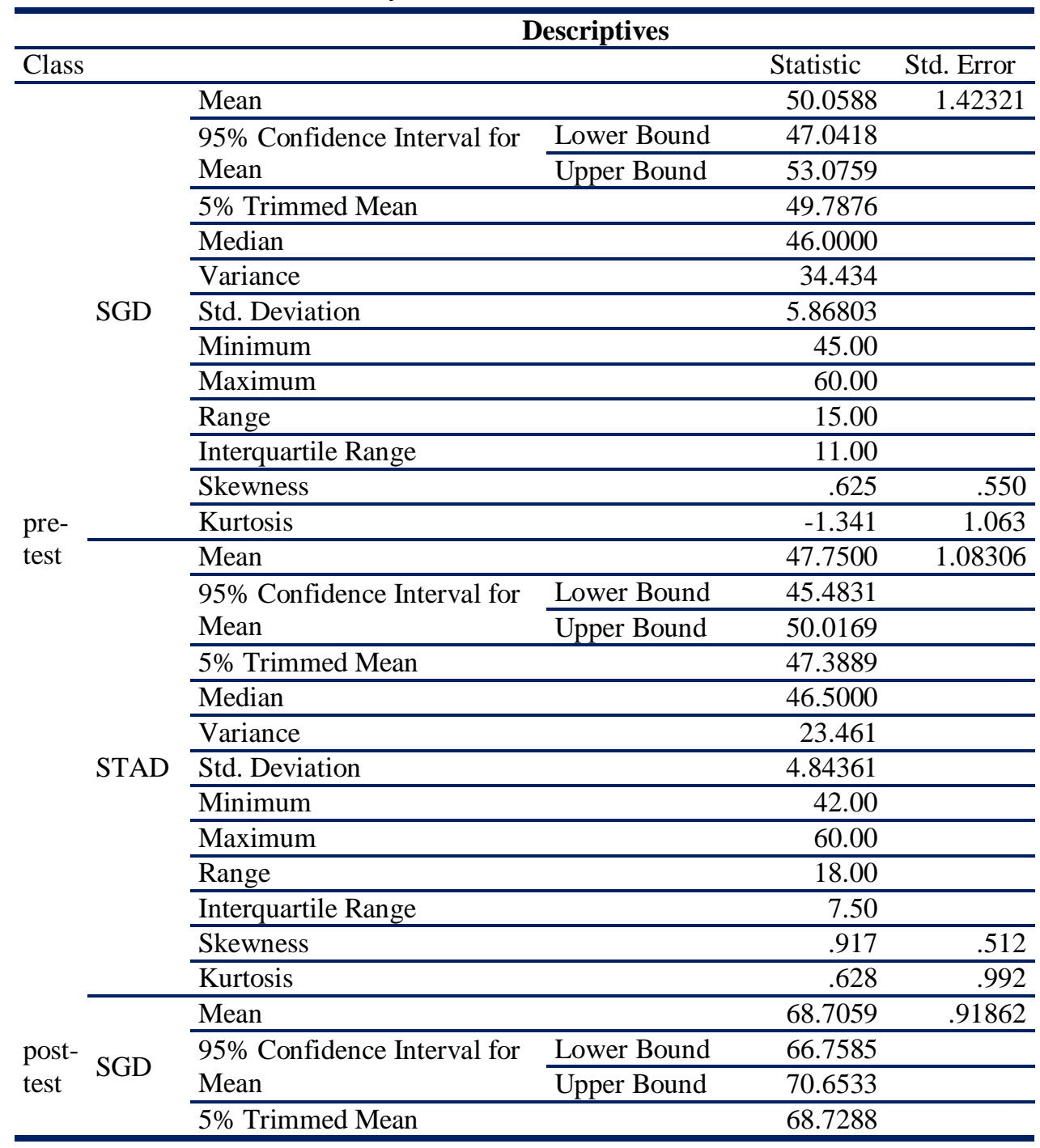




\begin{tabular}{|c|c|c|c|c|}
\hline & Median & & 70.0000 & \\
\hline & Variance & & 14.346 & \\
\hline & Std. Deviation & & 3.78756 & \\
\hline & Minimum & & 63.00 & \\
\hline & Maximum & & 74.00 & \\
\hline & Range & & 11.00 & \\
\hline & Interquartile Range & & 7.50 & \\
\hline & Skewness & & -.305 & .550 \\
\hline & Kurtosis & & -1.223 & 1.063 \\
\hline \multirow{13}{*}{ STAD } & Mean & & 63.1000 & .66846 \\
\hline & \multirow{2}{*}{$\begin{array}{l}95 \% \text { Confidence Interval for } \\
\text { Mean }\end{array}$} & Lower Bound & 61.7009 & \\
\hline & & Upper Bound & 64.4991 & \\
\hline & $5 \%$ Trimmed Mean & & 62.8889 & \\
\hline & Median & & 62.0000 & \\
\hline & Variance & & 8.937 & \\
\hline & Std. Deviation & & 2.98946 & \\
\hline & Minimum & & 60.00 & \\
\hline & Maximum & & 70.00 & \\
\hline & Range & & 10.00 & \\
\hline & Interquartile Range & & 5.00 & \\
\hline & Skewness & & .747 & .512 \\
\hline & Kurtosis & & -.316 & .992 \\
\hline
\end{tabular}

The result of the study showed that the teaching writing of descriptive text using Small Group Discussion learning method was better than using Students-Team Achievement Division learning method in encouraging the students' creativity and cooperatively learning with the group. The use of learning method both SGD and STAD in teaching writing of descriptive text did not show much difference. Students learn in the group in the same way in both those two learning methods when it was applied. However, some another step of activity after the learning done in STAD method that made students felt the learning took too much activity which made them less relax. While in its application SGD felt that the learning was more straightforward, as actually they got their self-learn the material in a group and done the task in a group as well.

\section{Conclusion and Suggestion}

\section{Conclusion}

Based on the result of the research at the tenth grade of students SMK SalafiyahKajen, Margoyoso, Small Group Discussion is better than Students-Team Achievement Division and can be applied in teaching writing especially descriptive text. The conclusion of this research can be drawn by the result of the data analysis such a below:

To find out the degree of the appropriateness', one between SGD and STAD in its application for teaching writing descriptive text at the tenth grade of SMK 
Salafiyah in the academic year of 2016/2017, the researcher took the average of pretest and post-test score on both classes. The average score of SGD class was 50.05 for pre-test and 68.70 for the post-test. While the average of STAD class was 47.75 for pre-test and 63.10 for post-test. It can be concluded that the result of post-test for SGD class was higher than STAD class. Therefore, Small Group Discussion method was more accessible and the suitable one to be applied in teaching writing descriptive text than STAD.

Small Group Discussion is a simpler learning method based group which more useful to be applied to teach writing at the tenth grade of SMK Salafiyah. The test of hypothesis using t-test formula showed that the value of the t-test is higher than the value of t-table. Based on the result of calculation of $t$-test, the value of t-test is 5.031 while the value of $t$-table on $a=5 \%$ is $(5.031>1.69)$. It can be concluded that there is a significant difference in students' achievement on students' writing of descriptive text on tenth-grade students of SMK SalafiyahKajenMargoyoso in academic year 2016/2017 between students who were thought by SGD and STAD. It means that teaching English of writing skill using Small Group Discussion more effective than using Students-Team Achievement Division. So, the hypothesis is accepted.

\section{Suggestion}

In teaching and learning writing especially which was done by the researcher, it must be found some weaknesses that caused by the lack of mastering the lesson or the less of knowledge and experience from the researcher, so that, may some suggestions below can be useful for students, teacher and other researcher for the next research. The suggestions are:

\section{Students}

After given the practice using Small Group Discussion method learning, students next can use the method not only in learning writing but it also can be used for any other subject. The simplicity and easiness of the method also make this method is useful enough to be applied anytime in the discussion session for any other topic as well.

2. Teacher

The teacher may use this strategy as one of learning method in her teaching. Although teacher has more experienced about group-based learning from the research which had done by researcher seems that SGD is potential as well to be applied. From this method, the teacher can take advantage of the simplicity and easiness application from this method.

\section{Other researchers}

From this research, it is hopefully helping the other researcher to take and use any information about the learning method to be developed in conducting the next research and may improve any lacks that are found in this research to get better research. 


\section{References}

Kane, Thomas S. (2002). The Oxford Essential Guide to Writing. New York: Oxford University Press.

Knap, Peter \& Watkins, Megan. (2005). Genre, Text, Grammar Technologies for Teaching and Assessing Writing. Australia: University of South Wales

Mertens, Donna M. 2009. Research and Evaluation in Education and Psychology: Integrating Diversity with Quantitative, Qualitative, and Mixed Methods. SAGE Publications, Inc. 3rd edition.

NurikaMustika. (2016). Writing Ability Improvement through Student Teams Achievement Divisions at Pirayanaw in Klonghin Wittaya School. University of Muhammadiyah Jember. ELLITEJournal of English Language, Literature, and Teaching Volume 01, No. 1

O’Malley, J Michael \&Chamot, Anna Uhl. (1990). Learning Strategies in Second Language Acquisition. USA: Cambridge University Press.

Rahmat, Edy. (2013). Improving Student's Achievement in Descriptive Text Writing through Small Group Discussion Technique (A Quasi-Experimental Study to the Tenth Grade students of SMAN 1 SukadanaKayong Utara Regency, in the academic year 2011/2012). Tanjungpura University.

Rusman. (2010). Model-Model Pembelajaran; Mengembangkan Profesionalisme Guru. Bandung: Rajawali press.

Slavin, Robert E. 2008. Cooperative Learning; Teori, Riset dan Praktik. Bandung: Nusa Media.

Umiyati. (2011). The Effectiveness of Using Small Group Interaction in Teaching Reading Comprehension; (Experimental Study at The Seventh Grade of SMP SunanBonang Tangerang), Department of English Education Faculty of Tarbiyah and Teacher Training Syarif Hidayatullah State Islamic University. Jakarta.

Warsono\& Haryanto. (2012). Pembelajaran Aktif Teori dan Assesment. Surabaya: RemajaRosdaKarya. 
65 | VISION: JOURNAL FOR LANGUAGE AND FOREIGN LANGUAGE LEARNING

Weigle, Sara Cushing. (2002). Assessing Writing. UK: Cambridge University Press. 